\begin{tabular}{l}
\hline OPEN O ACCESS Freely available online \\
http://www.banglajol.info/index.php/BJID/index \\
Brief Communication \\
Bangladesh Journal of Infectious Diseases \\
December 2020, Volume 7, Number 2, Page 113-114 \\
ISSN (Online) 2411-670X ISSN (Print) 2411-4820 \\
DOI: https://doi.org/10.3329/bjid.v7i2.51523
\end{tabular}

\title{
Spraying Disinfectants to Combat SARS-CoV-2 Transmission: Is it Fruitless Rather Than Fruitful?
}

\author{
Md. Sohel ${ }^{1}$, Md. Rashel Mahmod ${ }^{2}$
}

${ }^{1}$ Post-Graduate Student, Department of Biochemistry and Molecular Biology, Mawlana Bhashani Science and Technology University, Santosh, Tangail-1902, Bangladesh; ${ }^{2}$ Post-Graduate Student, Department of Biochemistry and Molecular Biology, Mawlana Bhashani Science and Technology University, Santosh, Tangail-1902, Bangladesh

[Received: 12 July 2020; Accepted: 30 August 2020; Published: 1 December 2020]

Coronavirus disease 2019 is the most serious and ongoing infectious disease to evolve rapidly, and considered world threats in $21^{\text {st }}$ centuries, including Bangladesh. As of November 12, 2020, Bangladesh has reported a total of 425,353 confirmed cases with about $1.5 \%$ deaths which accounted for $22^{\text {nd }}$ position around the whole world. It might be due to rapid transmission among the peoples via closed settings, such as domestic's surface, assisted living, and environments for residential institutions ${ }^{1}$. In health-care environments, furniture and other fixed items inside and outside of patient rooms as well as electronic equipment are more likely to be contaminated with the COVID-19 virus and hospital equipment that is non-critical like blood pressure cuffs, stethoscopes, wheelchairs, and incubators where certain medical procedures are performed. Besides, community settings such as publicly accessible buildings, faith-based community centers, stairway rails, road, markets, public transportation, and business settings are act as reservoirs for SARS-CoV-2 virus ${ }^{1-2}$. Peoples in the world, including Bangladesh are trying to suppress or delay the community transmission of COVID-19 by spraying disinfectants.

In Bangladesh, Government and private institutes have taken an integrated approach like cleaning programs and disinfecting surfaces of the environment in both the health and non-healthcare zone by using conventional disinfectants. For instance, Mirpur ${ }^{3}$, Magura ${ }^{4}$, Nirapad Nagarik Chamber $^{5}$, DMP ${ }^{4}$ Installed tunnel to prevent the spread of SARS-COV2. If someone walks into the tunnel, the 360-degree disinfectant spray inside the tunnel will automatically create a dense fog of disinfectant liquid.

Several compounds are widely used as disinfectants that contain hydrogen peroxide, chlorhexidine, $\mathrm{EDTA}^{6}$, chlorine dioxide, hypochlorite, sodium hypochlorite, bleaching powder solutions ${ }^{7}$. In addition, quaternary ammonium, organic acid, alcohol, aldehyde, iodine, and several halogenated compounds have strong positive effects for several microorganisms ${ }^{8}$.

It was supposed to be that the use of disinfection is beneficial in preventing infectious diseases ${ }^{8}$. Sattar et $\mathrm{al}^{9}$ assumed that several compounds like phenolic, chlorine, and ethanoic products inhibit transmission of rhinoviruses and rotavirus from stainless steel disks to finger pads.

The World Health Organization (WHO) cautioned that spraying of disinfectants on the open-air areas like roads and streets accomplished in different countries do not eradicate the novel coronavirus or SARS-CoV-2 from environments. Even this activity poses a health risk and in any case, it is not advised people to spray with disinfectants in a tunnel, cabinet, or chamber because such activities could be physically and psychologically harmful and would not decrease the capacity of an infected person to transmit the virus through droplets or touch. Furthermore, it is not recommended that disinfectants destroy the COVID-19 virus or others because disinfectants are inactivated by dirt and debris and it is not feasible to manually clean and remove all organic matter from such spaces. Dusts 
and debris inactivate disinfectants and it is not feasible to manually purify and destroy all organic matter from such spaces ${ }^{10}$.

It is not advised to spray disinfectants or to fog such substances, including chlorinated agents, formaldehyde, or quaternary ammonium compounds, because of sluggish health effects on workers and disinfectants cause irritation of both eyes and skin and can lead to potentially gastrointestinal effects like nausea and vomiting ${ }^{1-}$ 12. The combination of disinfectants during preparation and use causes respiratory irritation and can release potentially lethal gases, especially when amalgamated with hypochlorite solution ${ }^{10}$. Besides, to destroy SARS-CoV-2, spraying on porous surfaces, such as unpaved walkways and sidewalks was less effective. Streets and sidewalks are not known as infection reservoirs for COVID-19 and it can be unsafe for human health to spray disinfectants, even outdoors. Researchers were highlighted significant adverse health effects, even deaths that may occur after the consumption of methanol-containing hand sanitizer. Burn injuries and death occurred due to unconscious handling of flammable hand sanitizer followed by lighting a cigarette $^{13}$. Due to having the enormous noxious effect of spraying disinfectants, it should be wiser to wash hands, use face mask, and maintain personal distance rather than use disinfectants tunnels and air spray to prevent SARS-CoV-2 virus transmission among peoples.

\section{References}

1. Organization WH, Organization WH. Report of the WHOChina joint mission on coronavirus disease 2019 (COVID-19). Geneva; 2020.

2. Koh D. Occupational risks for COVID-19 infection. Occup Med (Lond). 2020;70(1):3.

3. Coronavirus: 'Artoonad' installs disinfection tunnel in Mirpur
4. Coronavirus: Two disinfecting tunnels installed in Magura. 5. IDEB cell makes 'Nirapad Nagarik Chamber' disinfection tunnel | The Business Standard.

6. McDonnell G, Russell A. Denver. Antiseptics and disinfectants: Activity, action, and resistance. Clin Microbiol Rev. 1999;12(1):147-79

7. Coronavirus: Bleaching powder mixed disinfectants harmful for human body | Dhaka Tribune.

8. Daschner F, Schuster A. Disinfection and the prevention of infectious disease: No adverse effects? Am J Infect Control. 2004;32(4):224-5.

9. Sattar SA, Jacobsen H, Springthorpe VS, Cusack TM, Rubino JR. Chemical disinfection to interrupt transfer of rhinovirus type 14 from environmental surfaces to hands. Appl Environ Microbiol. 1993;59(5):1579-85.

10. Organization WH. Cleaning and disinfection of environmental surfaces in the context of COVID-19: interim guidance, 15 May 2020. World Health Organization; 2020.

11. Mehtar S, Bulabula ANH, Nyandemoh H, Jambawai S. Deliberate exposure of humans to chlorine-the aftermath of Ebola in West Africa. Antimicrob Resist Infect Control. 2016;5(1):45.

12. Zock J-P, Plana E, Jarvis D, Antó JM, Kromhout H, Kennedy SM, et al. The use of household cleaning sprays and adult asthma: an international longitudinal study. Am J Respir Crit Care Med. 2007;176(8):735-41.

13. Doctor burnt in fire from hand sanitiser and lit cigarette dies at hospital.

\section{[Bangladesh Journal of Infectious Diseases, December 2020;7(2):113-114]}

Correspondence: Md. Sohel, Post-Graduate Student, Department of Biochemistry and Molecular Biology, Mawlana Bhashani Science and Technology University, Santosh, Tangail-1902, Bangladesh; biochemistmdsohel@gmail.com

Conflict of interest: Nil

How to cite this article: Sohel M, Mahmod MR. Spraying disinfectants to combat SARS-CoV-2 transmission: Is it fruitless rather than fruitful? Bangladesh $\mathrm{J}$ Infect Dis 2020;7(2):113-114

Copyright: (02020. Sohel and Mahmod. Published by Bangladesh Journal of Infectious Diseases. This article is published under the Creative Commons CC BY-NC License (https://creativecommons.org/licenses/by-nc/4.0/). This license permits use, distribution and reproduction in any medium, provided the original work is properly cited, and is not used for commercial purposes. 